\title{
Humour in online comments regarding Montenegro's accession to NATO
}

\author{
Milena Dževerdanović Pejović \\ University of Montenegro, Kotor \\ milenadz@ac.me
}

\begin{abstract}
The empirical analysis in this paper deals with establishing humour examples based on script opposition patterns in online comments regarding Montenegro's accession to NATO. It is established that the opposing scripts prevailing in the comments on political setting in Montenegro are heavily dependent on Montenegro's turbulent history and dominant collective scripts such as pride and bravery. As online comments are an emerging genre, a reference to the influence of computer-mediated communication was also made, where pragmatic interpretation called for the help of critical discourse analysis. The results show that the script opposition parameters enable not only linguistic but also pragmatic revelations about Montenegrin people and their chief values or scripts. Script opposition examples within commenters' standpoints are explained with reference to diachronic level and the modern values in Montenegro.
\end{abstract}

Keywords: humour, script opposition, critical discourse analysis, online comments.

\section{Introduction}

This paper deals with humorous comments in online articles in the national Montenegrin newspaper Vijesti on Montenegro becoming the $29^{\text {th }}$ member of the NATO alliance. The atmosphere in the media and social and political life of Montenegro was very tense and people's comments on online articles on NATO accession varied from arguments, explanations, back and forth discussion to 'flaming'.

There are two reasons for this. The division between supporters and non-supporters of NATO in Montenegro is a result of the continuation of decades-long disputes that reached a culmination when Montenegro regained independence at a referendum held in 2006 and left the state union with Serbia. From then onwards, Montenegro's independence was a trigger to achieve further goals of the leading political party towards the West, the tendency to accede to the EU and become a member of the NATO alliance. In the years to come, Montenegro introduced the euro as an official currency, Montenegrin language got the status of an official language that previously coexisted with the Serbian language. 
Online commenting is for sure nowadays a kind of vent for people to express their opinions. As regards Montenegro's accession to NATO, it was discovered that 70 percent of the comments contained a humorous note, functioning as an indirect medium of participation in the political life and personal deliberation. In fact, humour is inherently related to the peoples living in Montenegro, ex-Yugoslavia, or the Balkans, particularly in war scenarios that have affected this region for centuries (Koncewicz-Dziduch 2017).

Focusing on the analysis of four articles in the daily Vijesti over the course of three days and on the comments on these articles, the intertwining and clashes in the opposing scripts are represented in the online comments on NATO accession. According to Attardo (2001: 3), a script is a complex entity referring to prototypical information about the entity being described. Attardo's enlarged linguistic theory of humour is one of the reference works relevant to the analysis of humorous and ironic comments in this paper. A joke or humorous text is produced if the text has two opposing scripts and the humour comes as a realisation of how the two opposite scripts are compatible (fully or partially) with the context of the joke (Attardo 2001: 1). Attardo observed that humour is a vast category and there is no universal recipe to apply humour-based theory or establish a pattern in a humorous text. Jokes are all heavily dependent on the context, participants, culture, language intuition, register, media, and genre.

The choice to focus on humour in this paper is neither a political nor a judgment attitude it is rather based on the fact that Montenegro's accession to NATO, as a political choice, has provoked people to react in a humorous way, either as a kind of rebellion or as a way of deliberating on it. In this paper, the research is about NATO-triggered disputes in online comments in the Montenegrin daily Vijesti that shed light on inherently embedded scripts that exist in Montenegro, which are manifested through polarised values and through these opposing scripts made in humorous comments.

This paper shows not only how humour theory can be employed along with other critical discourse analysis tools to analyse cultural values and attitudes towards actual political situation, but also highlights the important role humour plays in public political discourse in Montenegro. The humour examples examined here primarily support the idea of basic mental script about Montenegrin people as a nation that will be explicated in the analysis section. A research on Montenegrin humour is scarce and not known to be a subject of academic papers.

As the analysis in this is paper is focused on comments, as a very popular internet genre, an overview of computer-mediated communication and theoretical background of this paper, along with the notion of a script, is given in section 2. Section 3 focuses on empirical analysis of articles that appeared at the time of NATO accession. The main research, that is, analysis of the comments is given in section 4 . The comments were classified on the basis of their content or the opposing scripts they contain, and were named accordingly. In section 5, the main conclusions drawn from analysis of the comments are presented.

\section{Theoretical background and relevant papers}

The analysis of comments in a specific political setting involves critical discourse analysis in the sense that knowledge of the context with the focus on power and political domination is essential (Van Dijk 2001). Of relevance to this paper is another term used by Van Dijk, which is the "contextualisation of the discourse", implying that interactional strategies relevant to the production of text and speech must be borne in mind. "Mapping" text and speech means revealing and resolving important aspects of communication (2009: 152). According to Fairclough, the basic stages in the application of the DA approach are description, interpretation, and explanation (1989: 26). Fairclough's focus on knowing the context in 
which text is created and the various genres and types of discourses that are created is the focus of this analysis of the articles.

One of the ideas related to the topic of this article is deeply founded in the critical discourse approach (Wodak et al. 2009), stating that discourse is deeply interrelated with the construction of national identities. There is no doubt that new political currents and ideologies represent a source of empirical materials for discourse analysts to develop their ideas (Torfing 2005: 2). Namely, discourse reveals how participants, deliberately or otherwise, mark their belonging to a certain culture and establish those national and archetypal features pertaining to it (language, culture, history). Bearing this in mind, the participant may dislike those cultures that conflict in any of the mentioned aspects (linguistic, cultural, or traditional) with his/her own.

On a larger scale, the works related to the topic of the paper mainly deal with the discursive features of NATO and its representation in the discourse of the media and global politics, mainly dealing with American versus Russian opposition. The methods are mainly from a critical discourse analysis approach, where empirical material such as NATO's official documents and speeches are analysed, especially in establishing policies towards the allies and Russia after the Cold War (Behnke 2013; Conrad 2011). For example, in terms of the Yugoslav conflict and the position of Montenegro as an ex-Yugoslav country, NATO intervention is seen as intervention by the alliance aimed at "providing a bedrock of hard security" or "the means to turn political declarations into coherent action" (Behnke 2013: 145). The analysed material indicates the ambivalence between Moscow and the alliance, reflected in discourse especially after 11 September, when the two countries identified common interests in maintaining security and the fight against terrorism, and defined themselves as "allies"; ever since, relations between the two countries have been characterised as "striking fluidity" (Conrad 2011: 9). The majority of results in these studies imply that NATO defines its military actions as "humanitarian interventions" aimed at maintaining "national sovereignty" and preserving "human rights". Of relevance to understanding the animosity by one part of the commenters on Montenegrin accession to NATO is fact that there was NATO military action against the FRY (Federal Republic of Yugoslavia) in 1999. ${ }^{1}$

There exists an increasing number of master's and $\mathrm{PhD}$ theses on NATO discourse, since it represents a popular state-of-the-art topic in current research, and NATO's written material can be said to be more available for empirical analysis. These empirical studies also apply modern aspects of computer-mediated communication (CMC) in online commenting as a new way of participating in public life and of deliberation (McMillan 2013; Sowers 2009).

\subsection{Computer-mediated communication}

Analysis of the online comments opens up an immense possibility for a discourse analyst to use discourse mechanisms to investigate the current "mood" of a specific community and gain a deeper "insight into the communicative households of inhabitants of the twenty-first century" (Gruber 2008: 59).

The emerging internet tools broaden the possibilities of social interaction and of commenters' participation in public discourse. Computer-mediated communication is one of many variants of media-based discourses and of communication in the public sphere realised via the internet. The concept of publicity and the public has changed, and it is computermediated communication and emerging internet genres that allow numerous ways for public opinion to be expressed. In his wording, Habermas predicted this kind of interrelation between social reality and public discourse. In modern era, our discourse is heavily preconditioned by technical capacities of communication tools (text messaging, Messenger, Skype). All of these encourage public deliberation in modern communication space or cyberspace but what has 
definitely encouraged public interaction are printed media or press with sections readers' comments.

The shift in the function of the principle of the publicity of the public sphere is a special realm. This shift can be clearly documented with regard to the transformation of the public sphere's preeminent institution - the press.

(Habermas 1991: 180)

The main feature of computer-mediated communication analysed in this paper is the lack of the metadiscourse features that apply face-to-face communication and the abuse of such communication, based on the fact that the participants are, for the most part, anonymous. Some participants are more assured when sitting in front of their computers and commenting, rather than taking part in face-to-face discussion. The impersonal nature and anonymity of communication allow for common forms of miscommunication to happen, in the form of manifested internet labels known as flaming, lurking, spamming, and identity deception (Riva 2001: 219).

The occurrence of new genres and electronically transmitted communication in CMC is challenging discourse analysts and socially oriented researchers to discover the links between the two aspects - computer technology, on the one side, and people and their ability to find various communicative ways to convey the message, on the other.

There is no doubt that people nowadays play an active role in communicating via computers and participating in public debates, thus indirectly engaging in sharing their views. The interactive features of the internet allow for various modes of expression.

As far as participation in online debates is concerned, it is evident that the internet allows for various electronic communities to have their own online space for action. It has certainly opened up possibilities for indirect participation in political life via the internet and participation in collective public discourse. The question is whether and to what extent this new freedom of discourse represents an act of democracy and allows deliberation, bearing in mind the controls exerted over weblogs, permitting only like-minded political opinions, which limits participants from expressing opposing views (Jones 2008: 433).

\subsection{The notion of scripts}

Dealing with humour in this paper as an omnipresent phenomenon was very challenging, given that humour represents an ethnographic, national, regional and local issue. In order to understand the humour used by commenters in this paper, an ethnographic view of the Montenegrin nation needs to be dealt with briefly. Although Montenegro gained its national independence and left the state union with Serbia in 2006, it shares a cultural and ethnographical heritage with former Yugoslav countries, and with the Balkans in the wider sense. It is also closest to Serbia and its people in terms of language, religion, and culture.

As stated, the notion of script used in this paper implies a collective rather than individual ethnographic image. Some classic mythical scripts used in ethnic jokes reveal something that is typical, for example, of Englishmen, Montenegrins, Scots, and similar collectives. Thus, the French are sexy, Italians and Montenegrins are lazy, Germans are militaristic, Jews are selfish, etc. (Attardo 1994:212). As regards people from the former Yugoslavia and the former Yugoslav ethnographical area, much can be said through jokes about Serbs, Montenegrins, Bosnians, and Croats. Evoking the old Yugoslavia, many online jokes reveal the stereotypes and humorous patterns of each nation or a common mentality. This kind of identity reproduced through jokes is an "identity produced and reproduced on a daily basis through narratives, which describe and inscribe social boundaries. Jokes are one of those 'daily' narratives" (Vučetić 2004: 25). 
In the context of the analysis in this paper, the Anglo script is identified with the current policy of Montenegro oriented toward European integration and NATO, which is diametrically opposed to the political current dedicated to Russian politics, its leader Putin and Balkan values. There is no doubt that intellectual movements in the Balkans are most closely related to language issues, and the question of language and the self-assertion of Balkan countries that started during Romanticism is closely related to national issues (Kitromilides 2006: 49).

As mentioned, basic jokes about Montenegrins are centred on their laziness and idleness. National souvenirs in Montenegro enforce this idea of a laissé-faire mentality, with pictures of Montenegrin men lying on the beach, doing nothing. Reluctance to work is embedded in the traditional patriarchal society where women do the housework and men do nothing, or rest a lot after work. One of the famous canonical commandments referenced on tourist magnets and souvenirs about Montenegrins are "love your bed as you love yourself" or "if you see someone resting, help him" (Koncewicz-Dziduch 2017).

\subsection{Clash of scripts in Montenegro}

The conflict-ridden political environment in Montenegro reached its height in 2006 when Montenegro became an independent state and left the state union with Serbia. Since then, two currents - pro-Montenegrin and pro-Serbian - have been divided between the West and East. The governing party, the Democratic Party of Socialists opted for EU entry and NATO integration, closer to the Anglo concept. They were supporters of the introduction of the Montenegrin language as an official language and as one of prerequisites for EU accession. On the other side, the advocates of union with Serbia supported the Serbian language, stating that Montenegrin and Serbian are the same language. In the disputes that arose between linguists and academics after 2006, the arguments centred on Njegoš, the Montenegrin poet and ruler, and on his famous work The Mountain Wreath. The pro-Serbian current, inclined towards Russian politics and culture, claims that Njegoš is a Serbian writer and the language of The Mountain Wreath is Serbian, referring to the fact that Njegoš was an admirer of the work of his contemporary Vuk Karadžić, the Serbian reformer whom he personally met in Vienna in 1833 and the fact that he made many visits to Russia and remained loyal to its people. Both of them shared an interest in preserving national languages and cherished folk tradition (Greenberg 2006: 96).

\section{Analysis of articles on NATO accession}

The first part of the analysis in this paper deals with an analysis of articles published in the daily Vijesti on the day before accession, on the day of accession, and in the days afterwards. To appreciate the discourse implications of comments on the texts on NATO accession derived from these articles, it is important to see how crucial political information of national importance is conveyed in the articles.

\subsection{Methodology and scope}

Montenegrin daily Vijesti established in 1997 is chosen as representative for the research in this paper as it is one of the most influential daily newspapers in Montenegro with leading circulation and the highest number of comments compared to other Montenegrin portals. The Vijesti portal (Vijesti.me) is among three largest national broadcasters and the most popular online portal with approximately 20 million page views per month. Of relevance for the analysis is the fact that Vijesti is slightly critical towards present government policy and 
leading party. The names of the authors of the articles are known as they are official journalists of the Vijesti daily. An average number of comments on the Vijesti portal is 60 .

As regards analytical tools, the method applied in the analysis is interpretative and focused on various linguistic levels, be it a semantic level such a repetitive use of words (brave, small, big), syntax (the use of imperative), or a tone of the speeches (ceremonial) or nonverbal behaviour (posture or politicians and the scene of flag raising for instance). All these elements of critical discourse analysis are explicit signals of power and dominance and show how power is exercised.

In light of the main critical discourse analysis concept relating to control and power, it can be said that articles published in Montenegrin daily Vijesti are in a way controlled (by the newspaper's journalists and editors) and involve control and power transmitted through online media. Accession to NATO can be said to have been served as a "final product" to Montenegrin citizens (due to the fact that this decision was voted on in parliament and not at a referendum, as was initially stated that it would be, which implies a kind of subtle dominant action and exercise of power).

\subsection{Article analysis and background}

The topics of the articles analysed during those three historic days contained within the statements by representatives of the NATO idea are about the concepts of a prosperous NATO, security, and a better future. The analysis of the articles preceding the analysis of comments in this paper is intentional. Actually, article analysis in this paper enables a reader to get familiar with factual pragmatic setting or political point of view in Montenegro necessary to grasp the situation that triggered readers to comment.

In the first article that provoked 87 comments (of the average 60 comments), titled Crnu Goru od NATO-a dijele sati [Montenegro is only hours away from NATO], NATO accession is seen as a historic turning point that was to happen within hours and is seen as a "dedication to the idea of NATO integration" despite the "challenges from the past". The article states that negotiations with NATO started at the end of 2006 when Montenegro received an invitation to access the Partnership for Peace, while an official invitation was sent in 2015. The text also emphasises that up until that date, NATO had expanded seven times to accommodate new members, and the countries that entered mainly entered in groups, which was the case with Croatia and Albania. Furthermore, the reader finds out that Montenegro stands alone as the third country in the region, becoming the 29th member of NATO, and not in a group. Finally, according to the chief of diplomacy, "the EU does not have to worry about Montenegrin security as one of its future members, as this will be guaranteed by NATO accession". The same message came from the leader of the ATLAS group who would be present in Washington at the accession ceremony - NATO accession brings not only security but also a "positive economic rating" and better possibilities for future development. In addition, he states that Montenegro is entering an alliance with one of the "most powerful" countries in the world. As expected, the focus of this introductory text before the act of accession is about security, with this noun occurring three times in the context.

The second analysed article has the highest number of comments (484). It is published in the daily Vijesti on the day Montenegro joined NATO, and is titled Crna Gora clanica NATO-a. Marković građanima: ujedinite se! [Montenegro a member of NATO; Marković to citizens: Unite!] The title is short and factual, typical of the language of block journalism. In the second sentence, Prime Minister Marković addressed the Montenegrin people. By sending the patriotic message "Unite" to the Montenegrin people, Marković confesses that he is aware of the two divisive currents towards NATO in Montenegro. The use of the imperative "unite" in his speech is his effort to use all his political and personal authority to reconcile a divided 
people. From a grammatical point of view, he is, at the same time, strengthening his confidence and "toughness" (Fairclough 1989:184). However, the body of the text shows the strict determination of Prime Minister Marković, standing proud at Montenegro's decision to join NATO. There is an interesting alteration between the first person possessive "my" in "my country" in the very first sentence of the premier's speech showing the premier's authority and the later shift to the inclusive "us" in the second part of the sentence.

"This is the big day for Montenegro, the day when my country becomes a member of NATO alliance." The discursive exponents of his determination is later managed with the inclusive "our" in "nobody will make decisions behind our backs", alluding to politics from the past led by the Serbian politician Milošević during the Montenegrin and Serbian state union until 2006. In addition, the rhetorical effect achieved in his speech is seen on the semantic level in collocation "to make sacrifice" and repetition of the word "sacrifice", as in "The Montenegrin people have made a great sacrifice to decide on their own future." "There is no smaller country, nor greater sacrifice." The first address by the prime minister in his first speech after NATO accession must have had an effect on the auditorium and refer to the Montenegrin nation's troublesome political past. The dominant lexemes in the speech refer to the main collective scripts ascribed to the Montenegrin people, such as pride, dignity, a heroic past, courage, bravery, independence. The concept of national identity after Montenegro gained independence in 2006 has been the main rhetorical and diplomatic language tool of the ruling party after Montenegro split from Serbia.

The third text (213 comments) was published in Vijesti on the day after accession is titled Zastava Crne Gore podignuta ispred sjedišta NATO [Flag of Montenegro raised in front of NATO headquarters]. The text is about the message that the president of Montenegro conveyed to the Montenegrin people. It is, as was expected, a continuation of a thread pointing to the strong links with the past and in particular the turbulent history of the Montenegrin people, their recognisable mentality (bravery and courage). It must be mentioned that recent Montenegrin political speeches refer a great deal to a book written by the Montenegrin writer and Duke Marko Miljanov. ${ }^{2}$

The third text is therefore an expression of gratitude to NATO for believing in Montenegro's persistence and for giving its politicians and policies credit for achieving these remarkable results in a short 10 -year period. The act of raising the flag was accompanied by introductory words by the president. The president was on a stage, proudly standing with members of his delegation and the highest NATO representatives, in front of the Montenegrin flag as it was being raised. This staging was rather predictable and organised according to protocol. The media followed this occasion in Brussels meticulously, particularly noting that the high-level representative - the Secretary General of NATO, Jens Stoltenberg - was present. His short speech was not as modest as of that of President Vujanović and he placed Montenegro on an equal pedestal with the other members of the alliance. "Montenegro is entering NATO as an equal, with a place at our table and an equal voice in shaping the future of the alliance". Apart from the "staging", which is a transparent part of political performance, there was another, more intricate concept of "backstage" (Wodak 2009: 14). In the scenery there was the speech of President Vujanović, aware of the public and opposing currents in the country on the one hand, and on the other hand aware of the NATO representatives awaiting a "convenient" message for this occasion. And the role of the media nowadays and "how politics is done" (Wodak 2009: xii) should not be forgotten. Within the present role of commercialised news, there is an evident shift toward the sensational even in politics, where soft and hard news (Macdonald 2003: 62) are closely interrelated and it has become difficult to differentiate between television, film, and the modern concepts of reality programmes.

To prove this sensationalism or "widespread appetite for scandals" (Wodak 2009: 20) related to the political background, a small digression relevant to the interpretation of the 
further text has to be made. Namely, at the collective photo shoot that had taken place a month before Montenegro's accession, President Trump pushed Montenegro's Prime Minister Marković aside and stood in front of him at NATO headquarters. The video gained wide circulation and provoked many comments from celebrities, politicians, and literary circles who judged this act by President Trump to be inappropriate. This also triggered many inferences in favour of the opponents of NATO in Montenegro, who mocked the premier as an irrelevant political figure and as a "yes-man" to the West, America, or more precisely, Trump's politics. In this view, the flag-raising ceremony was followed with rapt attention, and comments in public focused on President Trump and whether he would behave in the same way. Accidentally or not, in accordance with protocol or not, President Trump did not appear at the flag-raising ceremony.

At the beginning of his speech, President Vujanović used an overworn expression that has become a recognisable way of ending public speeches by Montenegrin representatives, ever since statehood was renewed in 2006. It goes like this: "Da je vječna Crna Gora!" [May Montenegro live forever!] The rhetorical effect of President Vujanović's second sentence at the ceremony's speech was obtained by the contrasting pairs "big" and "small", and "new" and "old", as in "This is not the end, this is the beginning of a new Montenegro". President Vujanović also said that Montenegro would be a reliable member of the alliance and used superlatives in a string of three, to highlight the strength of the NATO alliance as the "strongest, the most organised and most effective alliance in the history of mankind".

The fourth selected text published on the third day after accession Za ruganje NATO kazna 10.000 eura [Fine of $€ 10000$ for mocking NATO] attracted as many as 213 comments. The text clearly states that mocking the Montenegrin flag, or national symbols such as the national anthem, the coat of arms or those of any other country which is in diplomatic relations with Montenegro, will result in a fine. The author of the text refers to Article 200 of the Law on Criminal Procedure "Attacking the reputation of a foreign country or international organisation". Furthermore, the author of the text implicitly provides an opposing view on the given act by saying that a member of the organisation HRA (Human Rights Action) states that this act does not make sense as it does not include other countries or organisations, and also is in conflict with the basic human right of freedom of expression. The journalist then reports an interview with a political opponent of the ruling party, known to have burnt the NATO flag on two occasions, who finds that it is only a test for the regime, as everybody has the right to express their political choice and elementary freedoms.

However, it is stated in the text that mocking NATO is exempted in some cases, as in the journalist's profession, political activities or literary or scientific works. These exemptions were the subject of later commenters, who were guessing in their humorous remarks in which situations NATO can be mocked or not. These were comments questioning whether someone can mock the European Union and Serbia ("it means we can mock the European Union; do we have diplomatic relations with Serbia?" and so on).

\section{Analysis of online comments on articles about NATO accession}

The main analysis in this second part of the paper is about the comments on the articles analysed in section 3. It introduces the main intention of the author, which is to show how the opposing scripts contained in the humorous comments reveal knowledge about Montenegro and its collective values, intertwining the past and present. 


\subsection{Methodology and theoretical approach}

The approach used in this part of the paper focuses on analysis of online comments $(1,100$ comments) derived from the analysed articles (see section 3). Of this number, 660 comments are of humorous nature whereas the other belong to argumentation, offenses, graphics, or symbols (emoticons), and are not the subject of analysis in this paper. As regards comments of humorous nature, various humour techniques are combined and they are explained in the analysis of individual comments. For example, sarcasm prevails in the group of comments referring to Montenegrin poor military fitness to enter NATO, whereas metaphor prevails in comments where Montenegro is seen as future terrorist playground. Therefore, humour techniques prevailing in the comments are not quantified as some of the comments contain more than one humour exponent. The qualitative or interpretative method is therefore used to explain examples of humour techniques within an analysed comment.

Attardo's theory is known as the General Theory of Verbal Humour (GTVH) and is an upgraded version of Raskin's earlier Script-Based Semantic Theory of Humour (SSTH). Attardo's approach is more comprehensive in that it includes a pragmatic and meta-approach or intertextual approach to humour analysis in literary texts and modern genres (Attardo 1994: 222). Also, regardless of the type of humorous text, humour is always about some form of script opposition and a distortion of expected logic, a mistake in reasoning, or wordplay at any of the linguistic levels.

In elaborating his GTVH, Attardo expanded the already established script opposition (SO) parameter set forward by Raskin, of relevance to the humorous text (Attardo 2001: 20), who isolated the three major semantic oppositions in jokes: "actual/non-actual", "normal/abnormal", "possible/impossible". Depending on the context of analysis these oppositions were lately expanded with "sex/no-sex", "good/bad", "live/dead", "obscene/noobscene", "money/no money", "high/low stature".

In addition to the script opposition set in SSTH by Raskin, Attardo added Knowledge Resources (KR) to his GTHV necessary to generate a joke. These are: script opposition (SO); the logic mechanism (LM); the target (TA); the narrative strategy (NS); the language (LA); and the situation (SI).

The stated parameters are applied in the analysis of online comments in the further text and this can be said to be a challenging undertaking. Online comments, to the author's knowledge, have not been a subject of analysis using Attardo's model, as this has been applied rather to literary genres. Therefore, the challenge in this paper was to come to grips with online comments as a rather uncensored and deliberate discourse happening simultaneously and exploiting many linguistic means at all linguistic levels. Also, the fact is that humour is heavily context-dependent and that by translating Montenegrin comments into English, a great deal of the original humorous intent is lost.

On a larger scale, firstly an empirical classification of the opposing scripts prevailing in the comments was carried out (Table 1). After that, an analysis of individual scripts was carried out according to the criteria presented by Attardo's model of analysis. Not all six criteria were always present in the sentence analysis, as some of them were not relevant in the given context. The interpretation of sentences is also complemented by critical discourse analysis and the interpretative method. These opposites tell us about Montenegrin mentality and key national values that Montenegrin people expressed in their small "cyberspace" in an important political situation for its people. 
Table 1. Opposing scripts in the comments on Montenegro's accession to NATO

\begin{tabular}{lc}
\hline Opposite scripts & Percentage of comments \\
\hline Montenegrin versus Serbian & 52.34 \\
\hline NATO versus ISIS/ISIL & 19.32 \\
Anglo versus Montenegrin & 9.32 \\
script & \\
\hline Miscellaneous & 19.02 \\
\hline
\end{tabular}

\subsection{Montenegrin versus Serbian script}

As can be seen from Table 1, the largest number of comments were between Serbian and Montenegrin advocates; this division goes back to Montenegro's renewal of statehood in 2006 when Montenegro left the state union with Serbia. Reading the comments revealed that the commenting on Montenegrin and Serbian relations is emotionally coloured and ranges from the rational, argumentative and emotional, to the language of hatred. The disagreement brought strong nationalist-oriented feelings from both sides. The pro-Serbian current in Montenegro based its arguments on the common history of the two nations, their culture, language, and ethnicity. In short, "within the Serbian-Montenegrin dispute, the other was not viewed as an enemy but, rather, as a close yet bad partner. The only difference lay in the fact that the remedy for one side was a renewal of the original bond, and for the other - divorce" (Pavićević 2009: 129).

As regards humorous comments, allusions are made to the question of Montenegrin origin. Serbs claim that Montenegrins do not exist as a separate nation because they are actually Serbs, whereas the Montenegrin current claims to be an independent nation with its own language and state. As emphasised before, commenters identify with Montenegro and America on the one side, or with Serbia and Russia on the other, or more literally understood, split between Western and Balkan values. In commenting on NATO accession (SI), the target (TA) in the following sentences (1) and (2) are Serbs in Montenegro; the pro-Montenegrin commenters infer that Montenegrin Serbs wish to identify their origin with Serbs in Serbia and the ironic effect is intensified by the use of the noun Serb three times in (1).

(1) Nije napravljen bensedin koji danas djeluje na Srbe. Naročito na crnogorske, koji oće da su Srbi mimo Srba.

[There hasn't been invented a sedative that has an effect on Serbs today. Especially on Montenegrin Serbs, who wish to be Serbs above Serbs.]

Article 2

In the second sentence the irony is achieved through the question as an often deployed rhetorical means, and the use of the word mahala [village] as an understatement (LM) contributing to the opposites of Montenegro as a small state and Serbia as a big one. The SO in the second sentence "small" versus "big" is one of the commonest and most overused arguments against Montenegro and its small territory. In the second part sarcasm is obtained through its analogy between Serbia and its mother Russia.

(2) Pa što ćeš u mahalu? Briši kod majčice (Srbije, Rusije)

[What are you looking for in this village? Go to your little mother (Serbia, Russia).]

Article 2

The following comment (3) is posted by a pro-Serbian supporter. It refers to the coexistence of Montenegrins and Serbs in Serbia and the fact that Montenegrins who have moved to live in neighbouring Serbia, particularly in the capital Belgrade, have prospered and are privileged to 
have obtained many top management jobs. The subtlety of the sentence irony is managed by the use of a precise number. Knowing that Montenegro numbers about 600000 citizens, the commenter implies that almost a third have left Montenegro and moved to Serbia in a search of a better life.

(3) Pitajte 200 i kusur hiljada Crnogoraca u Srbiji što se ne vrate u blagodet koji spominješ.

[Ask the two hundred and more thousand Montenegrins in Serbia why they don't return to the welfare that you mention.]

Article 1

In some examples of humorous comments, Montenegrin accession is seen as servile political behaviour:

(4) Vidjela žaba da se konji potkivaju pa i ona stala u red.

[A frog saw some horses getting shod and so also stood in line.]

Article 2

(5) Zna li se kako su naši uvriježeni zvaničnici putovali za Ameriku? Sa Montenegro Airlines ili Air Serbia?

[Does anyone know how our respected representatives travelled to America? By Montenegro Airlines or Air Serbia?]

Article 3

The sarcasm contained in sentence 4 makes uses of an archaic folk proverb implying snobbish behaviour by previously modest people who changed overnight and have become high-class. The allusion in sentence 5 is again to the fact that in the previous state union Montenegro and Serbia had a joint air fleet and presently neither country can boast a high-standard fleet. The characteristic SO implied from this group of comments is small/big, poverty/wealth, independent/servile.

\subsection{NATO versus ISIS}

The second group of comments analysed refers to the opposition based on polarised comments on NATO versus ISIS or ISIL. Pro-Serbian advocates and opponents of NATO are of the opinion that Montenegro, having chosen to support NATO, has literally declared itself an open territory for future terrorist attacks. In their comments they ironically underline the fact that Montenegro never freed itself from the Ottoman Empire. ${ }^{3}$

In the following example (6), the commenter uses irony to alert the audience to the reality of the current scenario in Montenegro or the situation (SI) in which Montenegro is a potential target. The SO is therefore contained in the opposition: unexpected/expected; terrorism/peace; sudden/regular, and the target TA is the Montenegrin government and NATO.

(6) Naglo skočila kvota na Isil u crnogorskim kladionicama.

[There is a sudden rise in bets on ISIL in Montenegrin betting shops.]

Article 2

The affirmative sentence as a narrative strategy (NS) is, at first glance, neutral but the use of the evidential "there is" introduces a kind of ironic observation about Montenegro's safety and poor economic state. The second allusion evokes one of the typical canonical traits for Montenegrins, and that is that Montenegrins are known as lazy people; therefore, they would rather spend time in betting shop than working. ${ }^{4}$

The next example introduces semantic opposition (SO) of Islamic state/Montenegro; bad/evil. The sarcasm obtained in sentence 7 emphasises the already mentioned argument used 
by opponents of NATO, and that is of Montenegro as a small country whose influence is irrelevant in the world of politics. At the level of syntax, there is a rhetorical and evidential "it" construction. The use of the adverb "even" (LA) is in indication of the commenter's ironic observation (NS) wondering if Montenegro exists as a country on the world map at all. The punch line comes, or the irony reaches its culmination, in the second part of the sentence which is a folk saying (LM):

(7) Pa dobro je da najzad Islamska država čuje za Crnu Goru da postoji.

Dobar glas daleko se čuje, a zao još dalje.

[It is good that finally Islamic state has heard that Montenegro even exists. Good news travels fast and bad news even faster.]

Article 2

Further comments contain the same idea regarding Montenegro's accession (SI) and again based on the SO: small/big, poor/rich, weak/mighty. Namely, Montenegro is not technically equipped enough to be a part of the big alliance and the target in the following example, sentence 8, here is Montenegro's army. Understatement is managed on a lexical level (LA) in a simple affirmative sentence by the use of "at least", questioning whether tools used in a traditional children's game (slings and shields) would do any job at all.

(8) Sad barem ove praćke i štitnike možete upotrebiti.

[Now, at least you can make use of these slings and shields.]

Article 2

The typical SO inferred from this group of comments are: safe/unsafe; terrorism/peace, Ottoman/European, East/West.

\subsection{Anglo versus Montenegrin script}

A very important cultural script that silently "rules" the world is the Anglo cultural script embedded in English culture and dominant through the English language as the primary language of intercultural communication. It is through the English language as lingua franca of the modern world that some Anglo cultural traits were imposed. As Weirzbicka prudently observes in her analysis of language examples, it is clear "how unrealistic the slogan 'yes' to English and 'no' to Anglo cultural values really is" (Weirzbicka 2006: 312). Hence, "cultural baggage" as Weirzbicka names it, is undoubtedly embedded in Anglo-English. Script is therefore a yardstick for comparing cultural norms in different cultures.

The notion of an Anglo script within the Anglo-Montenegrin opposition cannot be clearly demarcated from other scripts pervading in the comments. However, it is most referred to in the context of the economy and differences existing between the Anglo and Montenegrin lifestyles. In that sense, the concept of a small and carefree nation is in opposition to the neat and organised Western mentality and the inherent Montenegrin laziness is contrasted with workaholic Western Europeans.

(9) Volio bih te poslati u neku zapadnu državu upravo takvog kakav jesi, zajedljiv, primitivan, prkosan. Vratio bi se u Crnu Goru, sjeo u kafe i nastavio pljuvat po Crnoj Gori.

[I would like to send you to some Western country just as you are: biting, primitive, and defiant. (...) You would return to Montenegro, sit in a café and continue to spit on Montenegro.] Article 1

In most examples the SO drawn from this group of comments is: hardworking/lazy, organised/disorganised; planned/random, accurate/carefree. 


\subsection{Miscellaneous}

Many comments classified into this group refer to the issue of the economy and to the unsettled economic state in Montenegro. Allusions are made to the high level of unsolved cases of crime that have recently affected Montenegro and the high level of corruption. "Economic" phrases are mainly cliché phrases, such as in sentence 10, and refer to the longlasting economic effect that entry into NATO will bring Montenegro, such as increased taxes and decreased salaries. The SO found in the following example - fool/smart - illustrates the disappointment

of

a

commenter identifying with the large population in Montenegro and reflected in the inclusive first-person plural "we". The feeling of distrust is conveyed by the use of the aorist in the Montenegrin uđosmo [we entered] employed to refer to events that happened long ago.

(10) Uđosmo u NATO kao budala u kredit

[We entered NATO like a fool into credit.]

Article 3

The following sentence (11) about the poor economy (SI) contains irony within the logic mechanism of speculation, where the target again is the Montenegrin government. This is managed through a meta-narrative commentary:

(11) Sad će nam penzije skočiti na $2 \%$.

[Now our pensions will rise to $2 \%$.]

Article 3

(12) Ovo je jedna od najpametnijih izjava u istoriji višestranačja, ujedinite se, vi praznih džepova i oni sa milionima, ujedinite se.

[This is one of the smartest statements in the history of the multiparty system, unite, you with empty pockets, and those with millions, unite.]

Article 2

There is no doubt that the economy unifies commenters, regardless of the party they belong to $(13,14)$. Collective dissatisfaction with the situation in country is expressed in 13 and 14 and the overwhelming tone is malicious and sarcastic.

(13) Živim u državi đe je najbolji uspjeh izaći iz nje.

[I live in a country where the greatest success is in leaving it.]

Article 4

(14) Jel se ovo ne smijemo rugat onima koji nas kao ozbiljno shvataju ili uvažavaju našu mafiju?

[Does this mean that we must not mock those who allegedly take us seriously or appreciate our mafia?]

Article 4

(15) Znači možemo se rugati Evropskoj uniji

[It means we can mock the European Union.]

Article 4

\subsection{From Milo to Kim Jong-un}

A number of comments in this paper refer to individuals, from past rulers and poets, through current Montenegrin politicians, to foreign political actors (Table 2). 
Table 2. Individual references in online comments on Montenegro's accession to NATO in descending order

\begin{tabular}{ll}
\hline Person & Pro/against NATO \\
\hline Milo Đukanović (politician) & Pro NATO \\
\hline Njegoš (poet and ruler) & Pro/against NATO \\
\hline Duško Marković (politician) & Pro NATO \\
\hline Vladimir Putin (politican) & Against NATO \\
\hline Donald Trump (politician) & Pro NATO \\
\hline Kim Jong-un (politician) & Against NATO \\
\hline
\end{tabular}

The individual references analysed in the comments relate to national figures and famous politicians (in descending order) such as the Montenegrin poet and ruler Petar Petrović Njegoš (1813-51), the Russian President Vladimir Putin, the American President Donald Trump, the Montenegrin Prime Minister Duško Marković and the leader of the Democratic Party of Socialists, Milo Đukanović. There are three comments, in which opponents of NATO compare the act of entry to the rule of the president of North Korea, Kim Jong-un.

The reason why the majority of comments refer to "Milo" is because he was the prime minister of Montenegro at the time when Montenegro gained independence in 2006. In the comments Milo Đukanović is referred to as Milo, Milaš or as Vođa [leader], as the current leader of the ruling party that opted for NATO. The use of nicknames for the president can be seen as prevailing trend of the modern commercialised media, which has been decreasing the distance between formal and informal, things happening on the stage and behind the scenes, or as a way to imitate face-to-face communication (Šarić 2014: 134). In addition, three proNATO registered commenters have nicknames containing the name Milo, such as Milo_Kralju [Milo_King], tatamilo [fathermilo], or as a son of President Milo, as in BlažoMilov [Blažo of Milo].

In the following example (16), a humorous effect with NATO as a target (TA) is managed on the level of syntax by using one of the national Montenegrin wedding songs (LA) about proud parents as their son or daughter is getting married. Thus, the humour technique is here managed also through the peculiar sound (national wedding song). In addition, humorous effect is obtained in the metaphor or parallelism (LM) in the first sentence . Namely, Montenegro is compared to a bride, NATO is a groom and Milo Đukanović is the proud father of the bride. Semantic opposition is thus: groom/bride, unsafe/secure, enemy/friend. In the second part of the sentence the idea of an escape through marriage culminates in the punch line as the crescendo of the humorous note.

(16 ) Veseli se Milo GAZDA / Za NATO si bio vazda. / Sad udaje se Crna Gora / Da se spasi od zlotvora!!!!!

[Be cheerful Milo the boss, you have always been for NATO. Now Montenegro is getting married to save itself from the enemy!]

Article 4

Montenegrins have a tendency to cherish their tradition and national folklore, and Gorski Vijenac [The Mountain Wreath], written by Petar Petrović Njegoš in 1846, is a collective 
mirror of the glorious Montenegrin past. In the comments in this paper, many references are made to The Mountain Wreath by both the pro-Montenegrin and pro-Serbian sides. Thus, the commenters who are against NATO mostly employ distorted quotations from Njegoš, aware that the main topic of The Mountain Wreath is about betrayal. Thus they identify entry into NATO with Montenegro's change of religion during the Ottoman domination in the early 1700s. The plot of this masterpiece drama play is the effort of Prince-Bishop Danilo to kill Islamised Montenegrins or return them to the Orthodox religion. Idioms implying this scenario from the past are a "lost face" or a "lost wreath" (17) and the noun "coward" or, as used in (18), the adjective kukavni [cowardly] are employed to support this point. The following sentences from The Mountain Wreath are loaded with sarcasm targeted against Montenegrin people, while an analogy is made with Islamised Montenegrins in the past.

(17) Da, viteza sustopice tragičeski konac prati: / tvojoj glavi bi suđeno za v’jenac svoj prodati! [Yes, a tragic end follows the knight at pace: your head will be judged for your sold wreath!] Article 2

(18) A moj kukavni rod mrtvijem snom spava

[My cowardly people sleep a deep and lifeless sleep.]

Article 2

The third group of individual references refer to the current prime minister of Montenegro, Duško Marković. His policies are seen as a continuation of those of Milo Đukanović and he is less commented on. Curiously, rather than highlighting his political actions (since credit for NATO accession is given to the former prime minister, Milo Đukanović), the most commenters allude to the occasion when the American president pushed him aside during the collective visit by NATO high-level representatives to the alliance's headquarters in Brussels.

It seems that this occasion has overshadowed his political actions and it identifies his policies in relation to this event. In the following examples, anti-NATO commenters allude to this unfortunate pushing and a humorous (ironic) thread is contained in the adverb "officially" (19). The semantic opposition (SO) is therefore official/unofficial, us/they, and the target (TA) is undoubtedly the Montenegrin government - NATO/Montenegro. All these pictorial details provoked a witticism:

(19) Sad mogu zvanično da se ćuškaju sa nama.

[Now they can officially push us around.]

Article 2

Trump, Putin and Kim Jong-un appear in the analysed comments in the context of autocratic behaviour, as in sentences 20 and 21. In most cases, the countries ruled over by the mentioned leaders are taken as symbols of autocratic rule. This juxtaposition is obtained by equating democracy and tyranny. The most frequent SO are: democracy/tyranny, East/West.

(20) Obrnuto, nevini se tuku tamo gdje nije zapadna demokratija, recimo u Putinovoj Rusiji.

[On the contrary, innocent people fight where Western democracy is not present, like in Putin's Russia.]

Article 2

(21) Sjeverna Koreja je za nas demokratija.

[North Korea is democracy for us.]

Article 1 


\section{Conclusion}

The initial point that in this paper was to analyse online humorous comments on NATO accession during a very important period of Montenegrin history. This analysis necessitated a better explanation of the sensitive political setting present in the days before and after accession. In this light, the first part of the empirical analysis of the articles, from which the comments analysed in the second part are drawn, presents the pragmatic setting or background.

As pointed out, the discourse analysis approach in this paper allows to interpret the discourse behaviour of Montenegrin politicians in this time of historical upheaval for Montenegro, accession to NATO. Under the spotlight of GTHV theory employed within critical discourse analysis, it turns out that political representatives are very conversant in selecting particular rhetorical means that contribute to reviving the collective scripts embedded in Montenegrin history and the emotions related to their homeland and origin. The scripts very much dominant in the discourse of representatives are obraz [honour], hrabrost [bravery], dostojanstvo [dignity], nezavisnost [independence], podnijeti žrtvu [make a sacrifice] and the contrast between small and big (referring to Montenegro and the alliance).

The comments analysed in the paper took as their starting point the General Theory of Verbal Humour set forward by Attardo, where script opposition was taken as the chief element of a joke or humorous line. Additional elements of jokes, such as the logic mechanism, narrative strategy, target, language, and situation were analysed, where this was relevant to the particular example. As the online comments which we analysed show, the basic trait of the humorous note in the online comments about NATO relies on the clash of opposing scripts prevalent in Montenegro. Some of them are heavily related to history (Serbian and Montenegrin relations, the language issue) and extend to the present and the future (Montenegro's orientation toward the West and Serbia's towards the East). Therefore, the linguistic and meta-linguistic manifestations of jokes vary from the collective to the individual, the abstract and the concrete concerning Russia, America, the Western, or Eastern way of life, religion, organisation, and politicians (Putin, Trump and Đukanović). The linguistic ways of constructing jokes are rich and unpredictable, and they are reflected at all linguistic levels: whether as a question, irony, sarcasm, metaphor, a distorted proverb, and witticism.

Overall, the scripts that emerge from the analysis can be used to describe the Montenegrin nation and its main values. It is interesting to see that is through opposites that one may define or describe an entity. The most common scripts extrapolated from the analysis are old/new, traditional/modern, rich/poor, Ottoman/West, secure/unsafe, lazy/hardworking, small/big, peace/terrorism. In addition, regardless of the attitude of the polarised sides in Montenegro, pro-Serbian or Pro-Montenegrin, it may be concluded that the economy is the important joint factor that unites the polarised sides in the desire to live better. Without a doubt, humour in online comments, as a modern tool of expression of the modern internet generations, contains an important meta-linguistic meaning. In this paper, the notion of a script is taken as a collective, the focus is on ethnographic and cultural values prevalent in Montenegro. As the research of comments in this paper focuses on humour, it is evident that in jokes and in humorous discourse, some collective scripts are ascribed to specific nations, be they true or not, justifiable or otherwise. In this paper, a collective image prescribed to Montenegrins making the basis of humorous comments is of Montenegrins as lazy nation, unreliable and patriarchal and unwilling for changes. In this light, humour triggered by NATO accession in the comments analysed in this paper can be explained by the fact that Montenegro is in a kind of transition towards strengthening its national identity and traditional values on the one side and, on the other, aiming towards Western values (EU, NATO).

In this sense, contribution of this paper was to shed light on Montenegrin mentality and employ humour theory to reveal peculiarities of Montenegrin nation usually linguistically 
labelled as "a country in the Balkans", its humour so far under-examined in academic research. Recently, Balkan wars have become popular topics of stand-up comedians, along with jokes about ex-Yugoslav people (Üngör \& Verkerke 2015). Undoubtedly, a linguistic survey of humour in online comments as an emerging genre represents a valuable resource of future folk linguistic and pragmatic analysis.

\section{Notes}

NATO military actions against the FRY triggered a division between Serbia and Montenegro as the Montenegrin government opted for neutral diplomacy, distancing itself from Serbian policies and it managed to protect itself from NATO bombing.

2 'Examples of Humanity and Bravery' written by Marko Miljanov is important in grasping the Montenegrin national identity. The main message of the book, that has become a crucial aspect for understanding Montenegrin ethical values and recognising Montenegro's national identity, is "Bravery is defending yourself from others, and humanity is defending others from yourself."

${ }^{3}$ At the time of referendum in Montenegro, in May 2006 the politician Milo Đukanović was the Prime Minister of Montenegro. Supporters of an independent Montenegro to the largest extend have this politician to thank for Montenegro's independence and his policies oriented toward the EU and NATO.

${ }^{4}$ The influence of the Ottoman Empire which occupied the territory of the Balkans for almost 500 years has impacted the Montenegrin language, culture, and tradition. In that context, accession to NATO is seen by pro-Serbian advocates as a false attempt by Montenegro to get rid of Turkish and Islamic influence and to turn to the EU.

${ }^{5}$ In a paper about jokes as a group identity, Vučetić analyses many stereotypical examples of folk traits in ex-Yugoslav peoples. One of the jokes testifying to this group identity goes like this: A Slovene, a Bosnian and a Montenegrin run a 100-metre race. The Slovene wins. Why? The Montenegrin gave up, and the Bosnian lost his way.

\section{References}

Attardo, S. (1994). Linguistic Theories of Humour. Berlin, New York: Mouton de Gruyter.

Attardo, S. (2001). Humorous Texts: A Semantic and Pragmatic Analysis. Berlin, New York: Mouton de Gruyter.

Behnke, A. (2013). NATO's Security Discourse after the Cold War: Representing the West. London and New York: Routledge.

Conrad, M. (2011). NATO-Russia Relations under Putin: The Emergence and Decay of the Security Community? An Analysis of the Russian Discourse of NATO (2000-2008). Berlin: LIT Verlag.

Greenberg, D. R. (2006). Language and Identity in the Balkans. Oxford: Oxford University Press.

Gruber, H. (2008). 'Analysing communication in the new media', in Wodak R. \& Krzyzanowski M. (eds.), Qualitative Discourse Analysis in the Social Sciences, Basingstoke: Palgrave, MacMillan, pp. 54-77.

Fairclough, N. (1989). Language and Power. New York: Longman.

Habermas, J. (1991). The Structural Transformation of the Public Sphere: An Inquiry into a Category of a Bourgeois Society. Cambridge: MIT Press. 
Jones, H. R. (2008). 'Technology, democracy and participation in space', in Wodak R. \& Koller V. (eds), Handbook of Communication in Public Sphere, Berlin and New York: Mouton de Gruyter, pp. 429-446.

Kitromilides, P. M. (2006). 'The Enlightenment in Southeast Europe', in Trencsényi B. \& Kopeček M. (eds.), Discourses of Collective Identity in Central and Southeast Europe (1770-1945): Texts and Commentaries, Budapest \& New York: Central European University Press, pp. 45-57.

Koncewicz-Dziduch, E. (2017). 'Commentary piece: The sociocultural characteristics of Montenegrins - The negative message in positive jokes.' European Journal of Humour Research 5 (2), pp. 71-79. Available at:

https://europeanjournalofhumour.org/index.php/ejhr/article/view/198.

Macdonald, M. (2003). Exploring Media Discourse. London: Arnold.

McMillan, S. R. (2013). Threads of Deliberation: A Textual Analysis of Online News Comments, Master's of Arts thesis. Available at:

https://etd.ohiolink.edu/!etd.send_file?accession=ohiou1368025601\&disposition=inline (accessed 13 June 2018).

Pavićević, Đ. \& Đurović S. (2009). 'Relations between Montenegro and Serbia from 1991 to 2006: An analysis of media discourse', in Pål Kolstø (ed.), Media Discourse and the Yugoslav Conflicts: Representations of Self and Other, England: Ashgate, pp. 129-153.

Riva, G. (2001). 'Communicating in CMC: Making order out of miscommunication', in Anolli L., Ciceri R., \& Giuseppe R. (eds.), Say Not to Say: New Perspectives on Miscommunication, Amsterdam: IOS Press, pp. 204-230.

Sowers, C.A. (2009). Changes in Branding Strategy: A Discourse Analysis of NATO publications and speech regarding its Russian relationship and the NATO-Russia council, Master of Arts thesis, Available at:

https://scholarworks.gsu.edu/communication_theses/60/ (accessed 13 June 2018).

Šarić, Lj. \& Radanović Felberg T. (2014). 'Means of expressing and implying emotions and impoliteness in Croatian and Montenegrin public discourse'. Poznańskie Studia Slawistyczne, 9, pp. 123-148.

Torfing J. (2005) 'Discourse theory: Achievements, arguments and challenges', in Torfing J. \& Howarth, D. (eds.), Discourse Theory in European Politics: Identity, Policy and Governance, London: Palgrave, pp.1-32.

Üngör, U \& Verkerke V. (2015). 'Funny as hell: The functions of humour during and after genocide'. European Journal of Humour Research 3 (2/3), pp. 90-101. Available at: https://europeanjournalofhumour.org/index.php/ejhr/article/viewFile/119/pdf

Van Dijk, T. A. (2001). 'Principles of Critical Discourse Analysis', in Wetherell M, Taylor S, and Yates J. S. (eds.), Discourse Theory and Practice: A Reader, London: Sage Publications, pp. 300-317.

Van Dijk, T. A. (2009). Society and Discourse: How Social Contexts Influence Text and Talk. Cambridge: Cambridge University Press.

Vučetić, S. (2004). 'Identity is a joking matter: Intergroup humour in Bosnia'. Available at: http://soi.journals.yorku.ca/index.php/soi/article/view/8011/7167 (accessed 25 February 2017).

Wierzbicka, A. (2006). English: Meaning and Culture. Oxford: Oxford University Press.

Wierzbicka, A. (2005). Emotions across Languages and Cultures: Diversity and Universals. Cambridge: Cambridge University Press.

Wodak, R. (2009). The Discourse of Politics in Action: Politics as Usual. London: Palgrave.

Wodak, R, de Cillia R, Reisigl M. \& Liebhart K. (2009). The Discursive Construction of National Identity. Edinburgh: Edinburgh University Press. 
Analysed articles:

Article 1: Crnu Goru od NATO-a dijele sati (http://www.vijesti.me/vijesti/crnu-goru-od-natoa-dijele-sati-940912).

Article 2: Crna Gore Članica NATO; Marković građanima: Ujedinite se! (http://www.vijesti.me/vijesti/crna-gora-clanica-nato-markovic-gradanima-ujedinite-se941008).

Article 3: Zastava Crne Gore podignuta ispred NATO (http://www.vijesti.me/vijesti/zastavacrne-gore-podignuta-ispred-sjedista-nato-941281).

Article 4: Za ruganje NATO kazna 10.000 eura (http://www.vijesti.me/vijesti/za-ruganjenato-kazna-10000-eura-941362). 